\title{
Chemical composition and fatty acid profile of BRS Capiaçu ensiled at different regrowth ages
}

\section{Composição química e perfil de ácidos graxos do BRS Capiaçu ensilado em diferentes idades de rebrota}

\author{
Fernando César Ferraz Lopes ${ }^{1 *}$; Mirton José Frota Morenz ${ }^{2}$; Francisco José \\ da Silva Lédo; Jailton da Costa Carneiro²; Domingos Sávio Campos Paciullo; \\ Paulino José Melo Andrade ${ }^{2}$; Conrado Trigo de Moraes $^{3}$
}

\section{Highlights}

BRS Capiaçu harvested at up to 70 days of regrowth presented good nutritional value. Capiaçu forage at 50-70 days of regrowth showed the highest linoleic acid levels. Capiaçu forage at 50-70 days of regrowth showed the highest $\alpha$-linolenic acid levels. At 90-110 days of regrowth, the silage showed the highest levels of linoleic acid. At $90-110$ days of regrowth, the silage showed the highest levels of $\alpha$-linolenic acid.

\section{Abstract}

This study aimed to evaluate the chemical composition and fatty acid (FA) profile of chopped forage and silage of BRS Capiaçu elephant grass at four regrowth ages: 50, 70, 90 and 110 days. A randomized block design with five replications was used. The ensiling was carried out manually in experimental silos without wilting using no additives or bacterial inoculants. The results were analyzed using mixed models $(P<0.05)$. The model included treatment (regrowth age) as a fixed effect and block as a random effect. Linear and quadratic effects of the treatments were analyzed using orthogonal contrasts. There were linear increases in the dry matter ( $\left.\mathrm{DM}, \mathrm{g} \mathrm{kg}^{-1}\right)$ and lignin $\left(\mathrm{g} \mathrm{kg}^{-1} \mathrm{DM}\right)$ contents and linear reductions in the in vitro DM digestibility $\left(\mathrm{g} \mathrm{kg}^{-1}\right)$ of chopped grass and silage as a function of regrowth age $(P<0.001)$. Quadratic effects $(P \leq 0.01)$ were observed for the chopped grass contents $\left(\mathrm{g} \mathrm{kg}^{-1} \mathrm{DM}\right)$ of crude protein $(C P)$, ether extract $(E E)$ and neutral detergent fiber (NDF) as a function of regrowth age. There were linear decreases $(P<0.0001)$ in the $\mathrm{CP}$ content $\left(\mathrm{g} \mathrm{kg}^{-1} \mathrm{DM}\right)$ and $\mathrm{pH}$ and linear increases $(\mathrm{P}<0.001)$ in the EE and NDF contents $\left(\mathrm{g} \mathrm{kg}^{-1} \mathrm{DM}\right)$ in the silage as a function of regrowth age. There were linear decreases $(P<0.01)$ in the chopped grass contents and linear increases $(P<0.05)$ in the silage contents of total FAs, linoleic and $\alpha$-linolenic acids $\left(\mathrm{g} \mathrm{kg}^{-1} \mathrm{DM}\right)$ as

1 Analyst, Brazilian Agricultural Research Corporation, EMBRAPA Dairy Cattle, Juiz de Fora, MG, Brazil. E-mail: fernando.lopes@embrapa.br

2 Researchers, EMBRAPA Dairy Cattle, Juiz de Fora, MG, Brazil. E-mails: mirton.morenz@embrapa.br, francisco.ledo@ embrapa.br, jailton.carneiro@embrapa.br, domingos.paciullo@embrapa.br and paulino.andrade@embrapa.br

${ }^{3}$ Animal Scientist, Doctoral Student in Animal Science, Federal University of Viçosa, UFV, Viçosa, MG, Brazil. E-mail: com_tm@hotmail.com

* Author for correspondence

Received: Nov. 30, 2020 - Approved: Mar. 01, 2021 
a function of regrowth age. BRS Capiaçu elephant grass must be harvested at up to 70 days of regrowth to obtain forage with good nutritional value and the highest levels of linoleic and $\alpha$-linolenic acids ( $\mathrm{g} \mathrm{kg}^{-1} \mathrm{DM}$ ). To produce silages with adequate $\mathrm{pH}$ values and the highest levels of linoleic and $\alpha$-linolenic acids $\left(\mathrm{g} \mathrm{kg}^{-1}\right.$ DM), BRS Capiaçu must be harvested between 90 and 110 days of regrowth.

Key words: Linoleic acid. Linolenic acid. Pennisetum purpureum. Silage. Tropical grass.

\section{Resumo}

O estudo objetivou avaliar a composição química e o perfil de ácidos graxos (AG) da forragem e da silagem do capim-elefante BRS Capiaçu em quatro idades de rebrota (50, 70, 90 e 110 dias), sob delineamento em blocos casualizados, com cinco repetições. A ensilagem foi realizada manualmente em silos experimentais, sem pré-murchamento, aditivos ou inoculantes bacterianos. Os resultados foram analisados usando modelos mistos $(P<0,05)$, que incluíram o efeito fixo de tratamento (idade de rebrota) e efeito aleatório de bloco. Os efeitos lineares e quadráticos foram analisados por meio de contrastes ortogonais. Houve aumento linear nos teores de matéria seca - $M S\left(\mathrm{~g} \mathrm{~kg}^{-1}\right)$ e lignina $\left(\mathrm{g} \mathrm{kg}^{-1}\right.$ de $\left.\mathrm{MS}\right)$, e reduções lineares na digestibilidade in vitro da MS $\left(\mathrm{g} \mathrm{kg}^{-1}\right)$ da forragem e da silagem em função da idade de rebrota $(P<0,001)$. Efeitos quadráticos $(P \leq 0,01)$ foram observados na forragem para os teores $\left(\mathrm{g} \mathrm{kg}^{-1} \mathrm{de} \mathrm{MS}\right)$ de proteína bruta (PB), extrato etéreo (EE) e fibra em detergente neutro (FDN) em função da idade de rebrota. Houve reduções lineares $(P<0,0001)$ no teor de $P B\left(g^{~ k g}{ }^{-1}\right.$ de $\left.M S\right)$ e no $\mathrm{pH}$, e aumentos lineares $(P<0,001)$ nos teores de $E E$ e FDN ( $\mathrm{g} \mathrm{kg}^{-1}$ de MS) da silagem em função de idade de rebrota. Para os teores dos AG totais e dos ácidos linoleico e $\alpha$-linolênico ( $\mathrm{g} \mathrm{kg}^{-1}$ de $\left.\mathrm{MS}\right)$, houve reduções lineares $(P<0,01)$ na forragem e aumentos lineares $(P<0,05)$ na silagem em função da idade de rebrota. O BRS Capiaçu deve ser colhido até 70 dias de rebrota para obter forragem com bom valor nutricional e maiores teores dos ácidos linoleico e $\alpha$-linolênico $\left(\mathrm{g} \mathrm{kg}^{-1}\right.$ de MS). Para silagem com adequado $\mathrm{pH}$ e maiores teores dos ácidos linoleico e $\alpha$-linolênico ( $\mathrm{g} \mathrm{kg}^{-1}$ de $\mathrm{MS}$ ), o BRS Capiaçu deve ser colhido entre 90 e 110 dias de rebrota.

Palavras-chave: Ácido linoleico. Ácido linolênico. Gramínea tropical. Pennisetum purpureum. Silagem.

\section{Introduction}

Elephant grass [Cenchrus purpureus (Schumach.) Morrone (syn. Pennisetum purpureum Schumach.)] is one of the most traditional tropical grasses used for feeding dairy cattle in Brazil. Although it is recommended for rotational grazing, the most common form of use is chopped grass supplied in the trough by a cutting and transport system (Pereira, Morenz, Ledo, \& Ferreira, 2016b).

In 1991, Embrapa Dairy Cattle (Juiz de Fora, MG, Brazil) initiated an elephant grass breeding program, addressingthedevelopment of improved cultivars for use in feeding ruminants. In 2015, as part of this program, the cultivar BRS Capiaçu was launched; BRS Capiaçu presented high forage productivity with good nutritional value in addition to other desirable agronomic characteristics (Pereira et al., 2016a; Pereira, Lédo, \& Machado, 2017). BRS Capiaçu presented 35 to $67 \%$ higher productivity and 27 to $31 \%$ higher crude protein (CP) content than other elephant grass cultivars (Mineiro and Cameroon) (Pereira et al., 2017). BRS Capiaçu has excellent adaptation to mechanical harvest, and it has a lower production cost per hectare of dry 
matter (DM), CP and total digestible nutrients than other forages traditionally used for silage production (corn, sorghum and sugarcane) (Pereira et al., 2016a).

Despite their low FA content, forages are important sources of polyunsaturated fatty acids (PUFAs), notably $\alpha$-linolenic acid (cis-9, cis-12, cis-15 C18:3), and due to the high proportion of forages in dairy cattle diets, they strongly influence PUFA intake in dairy cows (Dewhurst, Shingfield, Lee, \& Scollan, 2006; Khan et al., 2015). Cows consuming forages containing high levels of $\alpha$-linolenic and linoleic acids (cis-9, cis-12 C18:2) have the potential to produce milk with an FA profile that is more nutritionally desirable for human health. These PUFAs and, to a lesser extent oleic acid (cis-9 C18:1) are substrates for vaccenic acid (trans-11 C18:1) production by ruminal microorganisms. Vaccenic acid is the precursor for the synthesis of 6497\% rumenic acid (cis-9, trans-11 CLA) in the mammary gland, being the major isomer of CLA (conjugated linoleic acid) in bovine milk (Shingfield, Bernard, Leroux, \& Chilliard, 2010). Anticarcinogenic, antidiabetogenic (type 2 diabetes), antiatherogenic and immunomodulatory properties have been attributed to this FA (B. Yang et al., 2015).

In a cut-and-carry system, when wellmanaged, elephant grass forage contains high levels of linoleic and $\alpha$-linolenic acids,

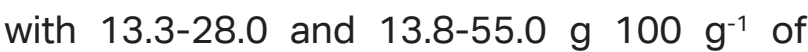
total FA, respectively (Lopes, Silva, Almeida, \& Gama, 2015). However, elephant grass has been scarcely investigated with respect to factors known to influence the forage FA profile. Aspects related to species/cultivar, age of regrowth, season of the year, nitrogen fertilization, temperature, light intensity and pasture management modulate the FA profiles of forages (Boufaïed et al., 2003; Dewhurst et al., 2006; Khan, Cone, Fievez, \& Hendriks, 2012; Glasser, Doreau, Maxin, \& Baumont, 2013; Elgersma, 2015; Khan et al., 2015). Knowledge of these factors could help to define management strategies to increase precursors for beneficial FAs in products of ruminants (Elgersma, 2015), especially $\alpha$-linolenic acid, the main FA in forages and the most useful for enhancing milk fat quality (Glasser et al., 2013).

For BRS Capiaçu grown in the rainy season of the Mata Atlântica Biome of Brazil, considering the biomass production and the nutritional quality of the forage, it is recommended that it be harvested at 50 to 70 days of regrowth to be supplied in the fresh chopped form. On the other hand, for silage production, mainly as a function of the DM content of the forage and to reach desirable fermentation in the silo, harvesting must be carried out when the plants reach ages between 90 and 110 days of regrowth (Pereira et al., 2016a). The forage FA content declines with plant maturity due to a decrease in the leaf/stem ratio and initiation of flowering and leaf senescence (Khan et al., 2015). Only two studies have presented the FA composition in elephant grass forage as a function of plant maturity: Khan et al. (2015) and MojicaRodríguez, Castro-Rincón, Carulla-Fornaguera and Lascano-Aguilar (2017) observed a reduction $(P<0.05)$ in the forage content of $\alpha$-linolenic acid as a function of plant maturity. In turn, the conservation method can also influence the FA composition, and the reported effects of ensiling on the total FA and $\alpha$-linolenic acid contents are contradictory. Many studies have reported maintenance or reduction (Arvidsson, Gustavsson, \& Martinsson, 2009; Alves, Cabrita, Jerónimo, 
Bessa, \& Fonseca, 2011; Ding, Long, \& Guo, 2013; Liu, Dong, \& Shao, 2018; Liu, Wu, \& Shao, 2019), while in others, increases in the total FA and/or in the $\alpha$-linolenic acid contents have been observed (Boufaïed et al., 2003; Bochicchio, Comellini, Marchetto Faeti, \& Della Casa, 2015), with this latter case also including unwilted (Glasser et al., 2013) or additivetreated silages (Dewhurst et al., 2006; Alves et al., 2011). However, no study was found on the FA profile of elephant grass silage.

This study was, therefore, designed to investigate the changes in forage and silage chemical composition, with particular emphasis on fatty acid composition, over a range of maturity levels at which BRS Capiaçu elephant grass is usually harvested and fed to dairy cattle.

\section{Materials and Methods}

The study was carried out at Embrapa Dairy Cattle (Coronel Pacheco, MG, Brazil) from February toSeptember 2015. The geographical coordinates are $21^{\circ} 33^{\prime} 22^{\prime \prime} \mathrm{S}$ latitude and $43^{\circ} 6^{\prime} 15^{\prime \prime} \mathrm{W}$ longitude, and the average altitude is $410 \mathrm{~m}$. The climate of the region, according to the Köppen classification, is of the Cwa type (mesothermal), with a well-defined hot/ rainy season (spring-summer) from October to March and a cold/dry season (autumn-winter) from April to September. The climatic data during the period of plant growth until harvest were obtained from a meteorological station located approximately $500 \mathrm{~m}$ away from the experimental area (Figure 1).

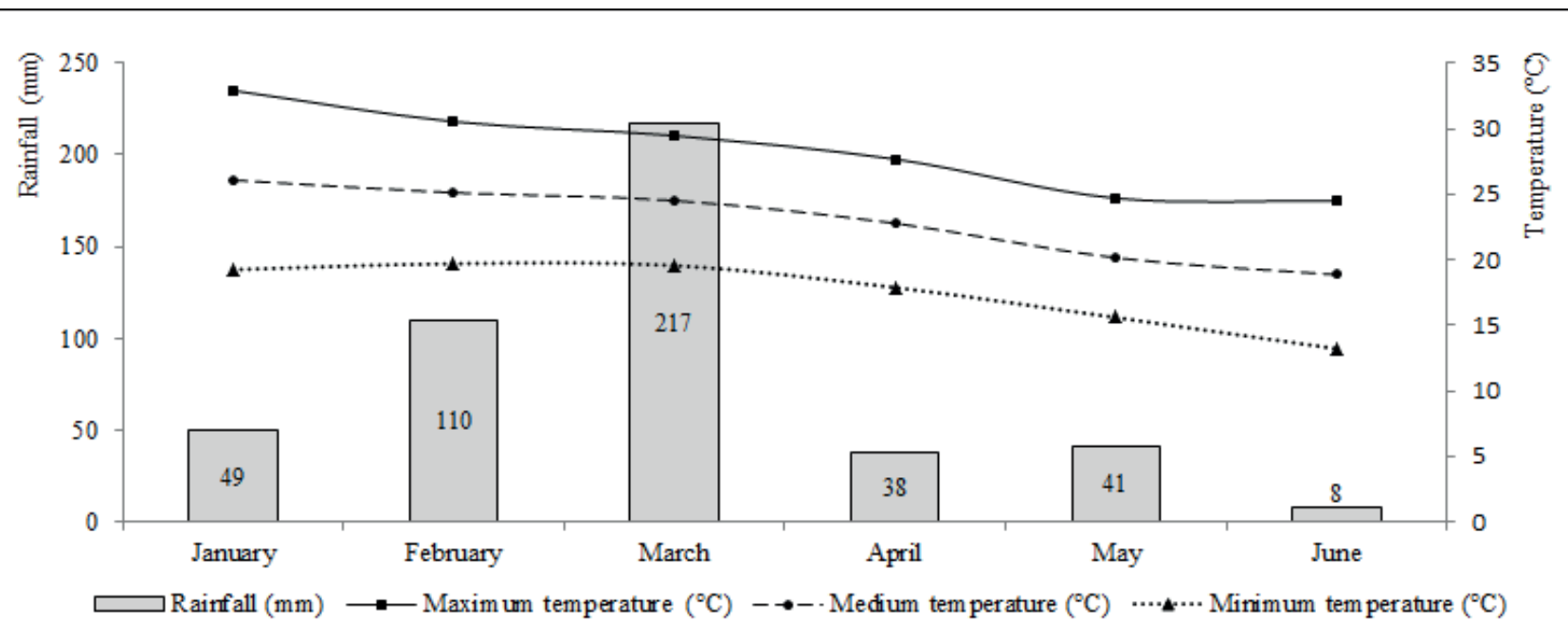

Figure 1. Climatic data during the period of plant growth until forage harvesting. Source: Instituto Nacional de Metereologia [INMET] (2020).

To evaluate the chemical composition and fatty acid (FA) profile of chopped forage and silage of BRS Capiaçu, four regrowth ages were defined: 50, 70, 90 and 110 days. These regrowth ages were chosen because this is the range of maturity at which BRS Capiaçu is usually harvested and fed to dairy cattle (Pereira et al., 2016a). A randomized block design with five replications was used, totaling 20 experimental plots. Each parcel was 
composed of 4 lines that were $5 \mathrm{~m}$ in length with a spacing of $1 \mathrm{~m}$. The useful area of the plot was formed by a $3 \mathrm{~m}$ center of 2 internal lines, totaling $6 \mathrm{~m}^{2}$. On February 23, 2015, in a flat area established with BRS Capiaçu, a standardization cutting of the plants was carried out at $10 \mathrm{~cm}$ from the ground level with the plots fertilized with $370 \mathrm{~kg} \mathrm{ha}^{-1}$ of NPK 20-05-20. The plots in the useful area were harvested manually on the mornings of April 14, May 4, May 24 and June 13, 2015 corresponding to the regrowth ages of 50,70 90 and 110 days, respectively, at a height of $10 \mathrm{~cm}$ from ground level using a $35 \mathrm{~cm}$ steel blade machete. Immediately after cutting, the plants belonging to each useful area of each plot were disintegrated (average forage particle size of 1-2 cm) in a stationary electric forage chopper. The forage of each plot was manually homogenized, and two $400 \mathrm{~g}$ subsamples were collected and frozen $\left(-20^{\circ} \mathrm{C}\right)$ to analyze the chemical composition and FA profile. The first subsample was thawed, predried $\left(55^{\circ} \mathrm{C}, 72 \mathrm{~h}\right)$, milled $(1 \mathrm{~mm})$ and analyzed at the Food Analysis Laboratory of Embrapa Dairy Cattle (Juiz de Fora, MG) for DM (at $105^{\circ} \mathrm{C}$ ), mineral matter (MM), crude protein $(C P)$, ether extract (EE), acid detergent fiber (FDA), neutral detergent fiber (NDF), lignin and in vitro DM digestibility (IVDMD), according to Detmann et al. (2012). The second subsample was lyophilized (model L120, Liotop, Liobras, São Carlos, SP, Brazil), ground (1 $\mathrm{mm})$ and analyzed for FA composition, according to Sukhija and Palmquist (1988), with adaptations (Palmquist \& Jenkins, 2003), at the Laboratory of Chromatography of Embrapa Dairy Cattle (Juiz de Fora, MG). Briefly, samples containing between 10 and $50 \mathrm{mg}$ of total FA were subjected to lipid extraction and transesterification using a one-step method based on acid catalysis $(10 \%$ methanolic $\mathrm{HCl}$ solution, v/v) under heating $\left(70^{\circ} \mathrm{C}\right.$ water bath for 2 h). Subsequently, the FA methyl esters (FAMEs) were separated and quantified in a gas chromatograph (Agilent 6890, Agilent Technologies Inc., Santa Clara, CA, USA) equipped with a flame ionization detector at $250^{\circ} \mathrm{C}, \mathrm{N}_{2}$ makeup $\left(30 \mathrm{~mL} \mathrm{~min}^{-1}\right.$ ) and a 10:1 ratio. By means of an automatic sampler, FAMEs were injected (volume of $1.0 \mu \mathrm{L}$, split 1:50, temperature of $250^{\circ} \mathrm{C}$ ) into a capillary column of high polarity (HP-FFAP, $25 \mathrm{~m} \times 0.2 \mathrm{~mm} \times$ $0.33 \mu \mathrm{m})$, with a stationary phase of modified polyethylene glycol nitroterafitalic acid, using $\mathrm{H}_{2}$ as the carrier gas at $1.0 \mathrm{~mL} \mathrm{~min}^{-1}$. The initial temperature of the oven was adjusted to $100^{\circ} \mathrm{C}$, with a heating ramp from $15^{\circ} \mathrm{C} \mathrm{min}^{-1}$ to $230^{\circ} \mathrm{C}$, maintained until the complete elution of the FAs of interest. The total FA content in the samples was calculated in $\mathrm{g} \mathrm{kg}^{-1} \mathrm{DM}$ based on the extrapolation of the internal standard area (C19:0; nonadecanoic acid; Sigma Aldrich CAS 646-30-0), added to the samples before extraction. FAs were identified by comparison of their retention times with those of reference FAME standards (Sigma Aldrich Inc.), being expressed in $\mathrm{g} 100 \mathrm{~g}^{-1}$ of total FA. Unfortunately, the forage sample for FA profile analysis corresponding to the regrowth age of 90 days was lost.

Before ensiling, the forage of each plot was manually homogenized and directly ensiled without wilting using no additives or bacterial inoculants. Ensiling was carried out in experimental PVC (polyvinyl chloride) silos (10 cm diameter and $30 \mathrm{~cm}$ height). The compaction of forage in the silo was carried out by hand with the aid of a socket made of wood, obtaining an average final density of forage mass of $\sim 700 \mathrm{~kg} \mathrm{~m}^{-3}$. The silos were closed with vulcanized rubber caps attached to a clamp, adapted with Bunsen valves to 
allow the escape of gases from fermentation. After 90 days of storage at room temperature in a covered location protected from sunlight, the silages were removed from the silos. After discarding $5 \mathrm{~cm}$ layers of silage from the bottom and top (which are often moldy), the contents of the silos were homogenized, and two subsamples of $400 \mathrm{~g}$ were collected and frozen $\left(-20^{\circ} \mathrm{C}\right)$ for chemical composition and FA profile analyses, as previously described for chopped forage. A third sample of silage $(100 \mathrm{~g})$ was pressed in a hydraulic press to obtain a juice, whose $\mathrm{pH}$ was determined with a digital potentiometer.

The results were analyzed according to a randomized block design replicated five times using the procedure for mixed models of SAS. The model included the fixed effect of treatment (regrowth age), and block was considered a random effect. Linear and quadratic effects of the treatments were analyzed using orthogonal contrasts. The results are reported as least square means, and effects were considered significant when $P<0.05$. Regression analyses of the variables as a function of regrowth age were performed using the REG procedure of SAS. Pearson's correlation studies were performed using the CORR procedure of SAS. Specifically, for forage FA profile results, due to the loss of forage samples collected at 90 days of regrowth, the levels of the treatments (regrowth age) were not equally spaced. Therefore, the ORPOL function in the CONTRAST statement in the Interactive Matrix Language (IML) procedure of SAS was used to determine orthogonal polynomial trend contrast coefficients. To compare the chemical composition $(50,70$, 90 and 110 days of regrowth) and FA profile
(50, 70 and 110 days of regrowth) of silage in relation to chopped forage, paired t-tests using the TTEST procedure of SAS were conducted for each regrowth age.

\section{Results and Discussion}

There were linear increases in DM $\left(\mathrm{g} \mathrm{kg}^{-1}\right)$ and lignin $\left(\mathrm{g} \mathrm{kg}^{-1} \mathrm{DM}\right)$ contents and a linear reduction in IVDMD $\left(\mathrm{g} \mathrm{kg}^{-1}\right)$ of forage as a function of regrowth age $(P<0.0001$; Table 1; Figures 2a, $2 f$ and 3). Quadratic effects were observed for the contents $\left(\mathrm{g} \mathrm{kg}^{-1} \mathrm{DM}\right)$ of $C P, E E, M M, A D F$ and NDF $(P<0.05$; Table 1; Figures $2 \mathrm{~b}, 2 \mathrm{c}, 2 \mathrm{~d}$ and $2 \mathrm{e})$. The DM $\left(\mathrm{g} \mathrm{kg}^{-1}\right), \mathrm{EE}$, ADF, NDF and lignin contents ( $\mathrm{g} \mathrm{kg}^{-1} \mathrm{DM}$ ) were linearly increased $(P \leq 0.0001)$, the $C P$ content $\left(\mathrm{g} \mathrm{kg}^{-1} \mathrm{DM}\right)$ and the IVDMD $\left(\mathrm{g} \mathrm{kg}^{-1}\right)$ were linearly decreased $(P<0.0001)$, and a quadratic effect was observed $(P=0.0002)$ for $M M$ content (Figure $2 \mathrm{~d}$ ) of silage as a function of regrowth age (Table 1; Figures $2 c, 2 e, 2 f$ and 3 ). There was a linear decrease $(P<0.0001)$ in the silage $\mathrm{pH}$ as a function of regrowth age (Table 1; Figure 3). Regardless of the regrowth age, the silage DM, EE and NDF contents were always higher $(P<0.05)$ than those in chopped grass, which, in turn, always had higher IVDMD and MM contents than the silage (Table 1; Figures $2 \mathrm{a}, 2 \mathrm{c}, 2 \mathrm{~d}, 2 \mathrm{e}$ and 3 ). For ADF and lignin, the silage had higher $(P<0.05)$ contents only at 50 days, being similar $(P>0.05)$ to the chopped grass at the other regrowth ages (Table 1; Figure 2f). Except at 90 days, when the $\mathrm{CP}$ contents were similar $(P=0.0785)$, in the other regrowth ages, the chopped grass always had higher $(\mathrm{P}<0.05) \mathrm{CP}$ contents than the silage (Table 1; Figure 2b). 
Table 1

Chemical composition ( $\mathrm{g} \mathrm{kg}^{-1}$ dry mater - DM) of chopped forage and silage of BRS Capiaçu elephant grass harvested at different regrowth ages

\begin{tabular}{|c|c|c|c|c|c|c|c|}
\hline \multirow{2}{*}{ Item } & \multicolumn{4}{|c|}{ Regrowth ages (days) } & \multirow{2}{*}{ SEM } & \multicolumn{2}{|c|}{ P-value } \\
\hline & 50 & 70 & 90 & 110 & & Linear & Quadratic \\
\hline \multicolumn{8}{|c|}{ Chopped forage } \\
\hline 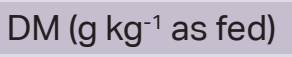 & 85.3 Bd & $126.2 \mathrm{Bc}$ & $149.4 \mathrm{Bb}$ & 179.3 Ba & 3.5533 & $<0.0001$ & 0.0300 \\
\hline Mineral matter & 160.0 Aa & 121.9 Ab & $115.0 \mathrm{Ac}$ & 110.1 Ac & 2.8121 & $<0.0001$ & $<0.0001$ \\
\hline IVDMD $\left(\mathrm{g} \mathrm{kg}^{-1}\right)^{\mathrm{b}}$ & $743.0 \mathrm{Aa}$ & $665.4 \mathrm{Ab}$ & $651.2 \mathrm{Ab}$ & $586.5 \mathrm{Ac}$ & 10.5676 & $<0.0001$ & 0.5215 \\
\hline Ether extract & $12.6 \mathrm{Ba}$ & 12.1 Bab & $10.6 \mathrm{Bb}$ & $13.5 \mathrm{Ba}$ & 0.5538 & 0.6423 & 0.0100 \\
\hline $\mathrm{ADF}^{\mathrm{c}}$ & $433.4 \mathrm{Bc}$ & $471.5 \mathrm{Ab}$ & $502.8 \mathrm{Aa}$ & $511.9 \mathrm{Aa}$ & 6.4407 & $<0.0001$ & 0.0159 \\
\hline $\mathrm{NDF}^{\mathrm{d}}$ & $604.5 \mathrm{Bc}$ & $662.5 \mathrm{Bb}$ & $682.4 \mathrm{Ba}$ & $685.8 \mathrm{Ba}$ & 6.0857 & $<0.0001$ & 0.0002 \\
\hline Lignin & 37.7 Bd & 58.1 Ac & $69.9 \mathrm{Bb}$ & $76.8 \mathrm{Aa}$ & 1.5870 & $<0.0001$ & $<0.0001$ \\
\hline Crude protein & 95.1 Aa & 77.2 Ab & $61.6 \mathrm{Ac}$ & $56.2 \mathrm{Ad}$ & 1.7650 & $<0.0001$ & 0.0003 \\
\hline \multicolumn{8}{|c|}{ Silage } \\
\hline DM (g kg ${ }^{-1}$ as fed) & 102.0 Ad & 138.7 Ac & 169.7 Ab & $190.8 \mathrm{Aa}$ & 4.5587 & $<0.0001$ & 0.0423 \\
\hline Mineral matter & $144.8 \mathrm{Ba}$ & 111.3 Bb & 100.5 Bc & $97.4 \mathrm{Bc}$ & 2.5444 & $<0.0001$ & 0.0002 \\
\hline IVDMD $\left(\mathrm{g} \mathrm{kg}^{-1}\right)^{\mathrm{b}}$ & $621.8 \mathrm{Ba}$ & 584.8 Bab & 547.7 Bbc & 518.2 Bc & 1.2160 & $<0.0001$ & 0.7631 \\
\hline Ether extract & $19.8 \mathrm{Ab}$ & $21.0 \mathrm{Ab}$ & 27.1 Aa & $27.0 \mathrm{Aa}$ & 1.3099 & 0.0001 & 0.5732 \\
\hline $\mathrm{ADF}^{\mathrm{c}}$ & $465.9 \mathrm{Ac}$ & 476.0 Abc & $491.9 \mathrm{Bb}$ & $510.3 \mathrm{Aa}$ & 5.3477 & $<0.0001$ & 0.4466 \\
\hline $\mathrm{NDF}^{\mathrm{d}}$ & $673.6 \mathrm{Ac}$ & $706.2 \mathrm{Ab}$ & 722.4 Aab & 737.9 Aa & 5.8294 & $<0.0001$ & 0.1686 \\
\hline Lignin & $60.6 \mathrm{Ab}$ & $62.3 \mathrm{Ab}$ & $75.9 \mathrm{Aa}$ & 78.1 Aa & 3.4613 & 0.0008 & 0.8871 \\
\hline Crude protein & $70.3 \mathrm{Ba}$ & $63.9 \mathrm{Bb}$ & 53.3 Bc & $51.2 \mathrm{Bc}$ & 2.0001 & $<0.0001$ & 0.3057 \\
\hline $\mathrm{pH}$ & $5.12 \mathrm{a}$ & $5.18 \mathrm{a}$ & $3.71 \mathrm{~b}$ & $3.85 b$ & 0.0834 & $<0.0001$ & 0.6822 \\
\hline
\end{tabular}

aFor each variable, means followed by the same letters, which are uppercase in the columns in the comparison between chopped forage versus silage in each regrowth age (paired t-test) and lowercase in the rows for comparison among days of regrowth, do not differ at $5 \%$ probability; ${ }^{\mathrm{b}} / \mathrm{n}$ vitro DM digestibility; ${ }^{\mathrm{C}}$ Acid detergent fiber; ${ }^{\mathrm{d}}$ Neutral detergent fiber.

There were linear $(P<0.001)$ increases in the contents $\left(\mathrm{g} \mathrm{kg}^{-1} \mathrm{DM}\right)$ of lauric (C12:0) and myristic (C14:0) acids in the chopped grass, while there were linear reductions $(P<0.01)$ in the contents of palmitic (C16:0), stearic (C18:0), oleic, linoleic, $\alpha$-linolenic and total FAs as a function of regrowth age (Table 2; Figures $4 a$ to $4 d$ ). For each day of increase in regrowth age between 50 and 110 days, reductions in chopped grass contents of $0.019,0.001$, $0.004,0.010,0.021$, and $0.052 \mathrm{~g} \mathrm{~kg}^{-1} \mathrm{DM}$ were observed for palmitic, stearic, oleic, linoleic, $\alpha$-linolenic and total FAs, respectively. There were linear reductions $(P<0.001)$ in the silage contents ( $\mathrm{g} \mathrm{kg}^{-1} \mathrm{DM}$ ) of lauric, palmitic and oleic acids, while the levels of linoleic and $\alpha$-linolenic acids and total FAs linearly increased $(P<0.05)$ as a function of regrowth age (Table 2; Figures $4 a$ to $4 d)$. There was no effect $(P>0.05)$ of the age of regrowth on the silage myristic acid content, while a quadratic effect $(P=0.0429)$ was observed for stearic acid (Table 2). At 50 and 70 days of regrowth, the contents $\left(\mathrm{g} \mathrm{kg}^{-1}\right.$ DM) of oleic, linoleic, $\alpha$-linolenic and total FAs were always higher $(P<0.05)$ in chopped grass than in silage. However, at 110 days of regrowth, 
there was no difference $(P>0.05)$ between chopped grass and silage in the contents of linoleic, $\alpha$-linolenic and total FAs, with the higher oleic acid content $(P=0.0143)$ remaining in the chopped grass (Table 2; Figures $4 a$ to 4d). Figure 5 presents the percentage changes (\%) in the silage contents ( $\mathrm{g} \mathrm{kg}^{-1} \mathrm{DM}$ ) of linoleic, $\alpha$-linolenic and total FAs compared to those of chopped grass harvested at different regrowth ages. Regardless of the regrowth age, there was no difference $(P>0.05)$ in stearic acid contents between silage and chopped grass.
For palmitic acid, only at 70 days of regrowth was a difference observed $(P=0.0272)$, with a higher content in chopped grass than silage (Table 2). Higher $(P<0.05)$ lauric and myristic acid contents were observed at 50 days of regrowth in silage, and lower $(P<0.001)$ contents were observed at 110 days. At 70 days of regrowth, there was no difference $(P>0.05)$ between silage and chopped grass for the lauric acid content, while the chopped grass showed a higher $(P=0.0170)$ content of myristic acid.

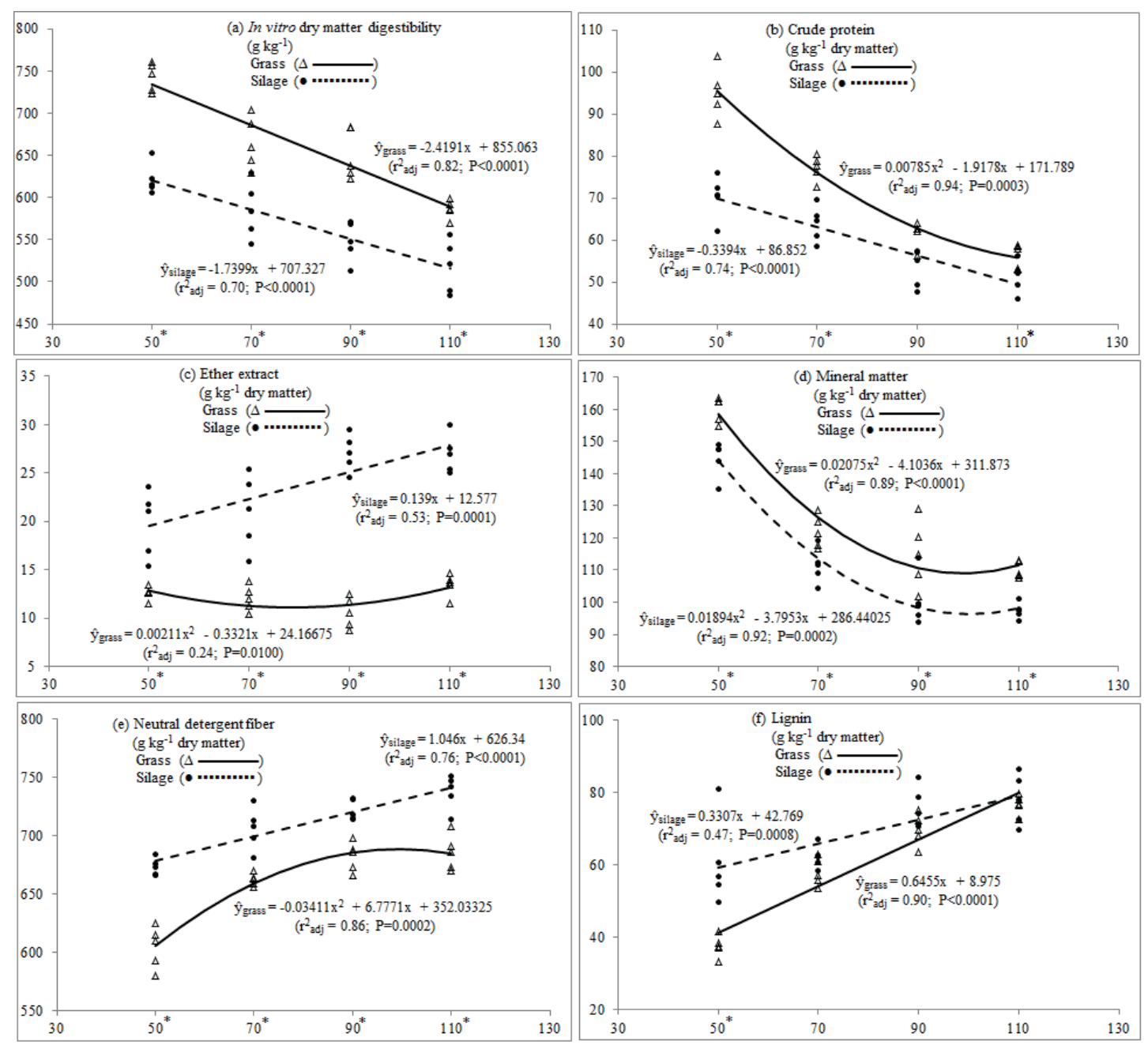

Figure 2. Changes in the chemical composition of chopped grass and silage of BRS Capiaçu harvested at different regrowth ages (days). *Asterisks beside the regrowth age indicate a difference $(\mathrm{P}<0.05)$ between chopped grass versus silage (paired t-test). 


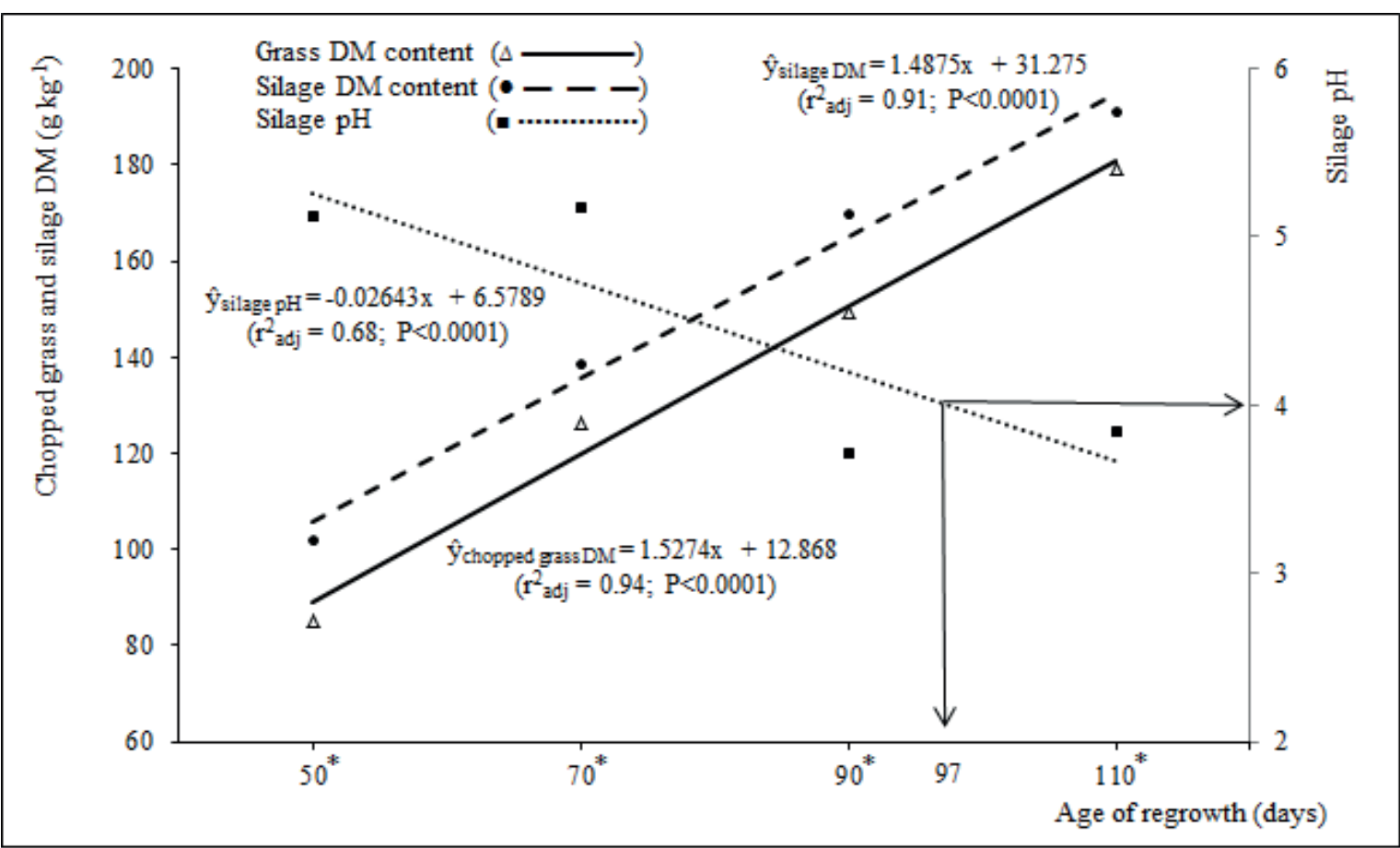

Figure 3. Changes in the silage $\mathrm{pH}$ and in the dry matter (DM) contents of chopped grass and silage of BRS Capiaçu harvested at different regrowth ages (days). *Asterisks beside the regrowth age indicate a difference $(\mathrm{P}<0.05)$ between chopped grass versus silage (paired t-test). 
Table 2

Fatty acid (FA) composition (g kg-1 dry mater) of chopped forage and silage of BRS Capiaçu elephant grass harvested at different regrowth ages

\begin{tabular}{|c|c|c|c|c|c|c|c|}
\hline \multirow{2}{*}{ Fatty acid } & \multicolumn{4}{|c|}{ Regrowth ages (days) $^{a}$} & \multirow{2}{*}{ SEM } & \multicolumn{2}{|c|}{ P-value } \\
\hline & 50 & 70 & 90 & 110 & & Linear & Quadratic \\
\hline \multicolumn{8}{|c|}{ Chopped forage } \\
\hline C12:0 & $0.071 \mathrm{Bb}$ & $0.083 \mathrm{Ab}$ & * & $0.134 \mathrm{Aa}$ & 0.0069 & 0.0001 & 0.3158 \\
\hline C14:0 & $0.047 \mathrm{Bc}$ & $0.056 \mathrm{Ab}$ & * & $0.077 \mathrm{Aa}$ & 0.0022 & $<0.0001$ & 0.7693 \\
\hline C16:0 & $3.264 \mathrm{Aa}$ & $2.645 \mathrm{Ab}$ & * & $2.043 \mathrm{Ac}$ & 0.0708 & $<0.0001$ & 0.0147 \\
\hline C18:0 & $0.209 \mathrm{Aa}$ & $0.171 \mathrm{Ab}$ & * & $0.165 \mathrm{Ab}$ & 0.0062 & 0.0006 & 0.0060 \\
\hline cis-9 C18:1 & $0.618 \mathrm{Aa}$ & $0.438 \mathrm{Ab}$ & * & $0.339 \mathrm{Ac}$ & 0.0160 & $<0.0001$ & 0.0024 \\
\hline cis-9, cis-12 C18:2 & $2.136 \mathrm{Aa}$ & $2.054 \mathrm{Aa}$ & * & $1.541 \mathrm{Ab}$ & 0.0882 & 0.0003 & 0.2284 \\
\hline $\operatorname{LnA}^{b}$ & $2.716 \mathrm{Aa}$ & $2.525 \mathrm{Aa}$ & * & $1.498 \mathrm{Ab}$ & 0.1955 & 0.0014 & 0.3911 \\
\hline Total FA & $10.350 \mathrm{Aa}$ & $9.188 \mathrm{Ab}$ & * & 7.180 Ac & 0.3851 & $<0.0001$ & 0.7961 \\
\hline \multicolumn{8}{|c|}{ Silage } \\
\hline C12:0 & $0.173 \mathrm{Aa}$ & $0.108 \mathrm{Ab}$ & $0.082 \mathrm{c}$ & $0.074 \mathrm{Bc}$ & 0.0072 & $<0.0001$ & 0.0023 \\
\hline C14:0 & $0.055 \mathrm{Aa}$ & $0.044 \mathrm{Bb}$ & $0.051 \mathrm{ac}$ & $0.048 \mathrm{Bbc}$ & 0.0027 & 0.1620 & 0.0895 \\
\hline C16:0 & $2.870 \mathrm{Aa}$ & $2.395 \mathrm{Bb}$ & $2.348 b$ & $2.062 \mathrm{Ab}$ & 0.1248 & 0.0008 & 0.4622 \\
\hline C18:0 & $0.201 \mathrm{Aa}$ & $0.162 \mathrm{Ab}$ & $0.166 \mathrm{~b}$ & $0.162 \mathrm{Ab}$ & 0.0077 & 0.0071 & 0.0429 \\
\hline cis-9 C18:1 & $0.331 \mathrm{Ba}$ & $0.277 \mathrm{Bb}$ & $0.255 \mathrm{bc}$ & $0.214 \mathrm{Bc}$ & 0.0142 & $<0.0001$ & 0.6314 \\
\hline cis-9, cis-12 C18:2 & $0.895 \mathrm{Bb}$ & $1.144 \mathrm{Bb}$ & $1.542 \mathrm{a}$ & $1.532 \mathrm{Aa}$ & 0.1178 & 0.0009 & 0.2920 \\
\hline $\operatorname{LnA}^{b}$ & $1.039 \mathrm{Bb}$ & $1.176 \mathrm{Bb}$ & $1.874 \mathrm{a}$ & $1.891 \mathrm{Aa}$ & 0.1870 & 0.0021 & 0.7530 \\
\hline Total FA & $6.618 \mathrm{Ba}$ & $6.687 \mathrm{Ba}$ & $7.307 a$ & $7.522 \mathrm{Aa}$ & 0.3158 & 0.0316 & 0.8161 \\
\hline
\end{tabular}

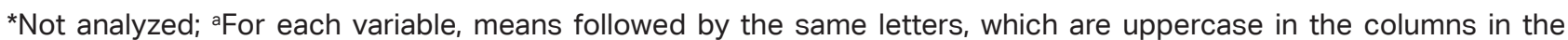
comparison between chopped forage versus silage in each regrowth age (paired t-test) and lowercase in the rows for comparison among days of regrowth, do not differ at $5 \%$ probability; ${ }^{b} \alpha$-Linolenic acid (cis- 9 , cis-12, cis-15 C18:3). 

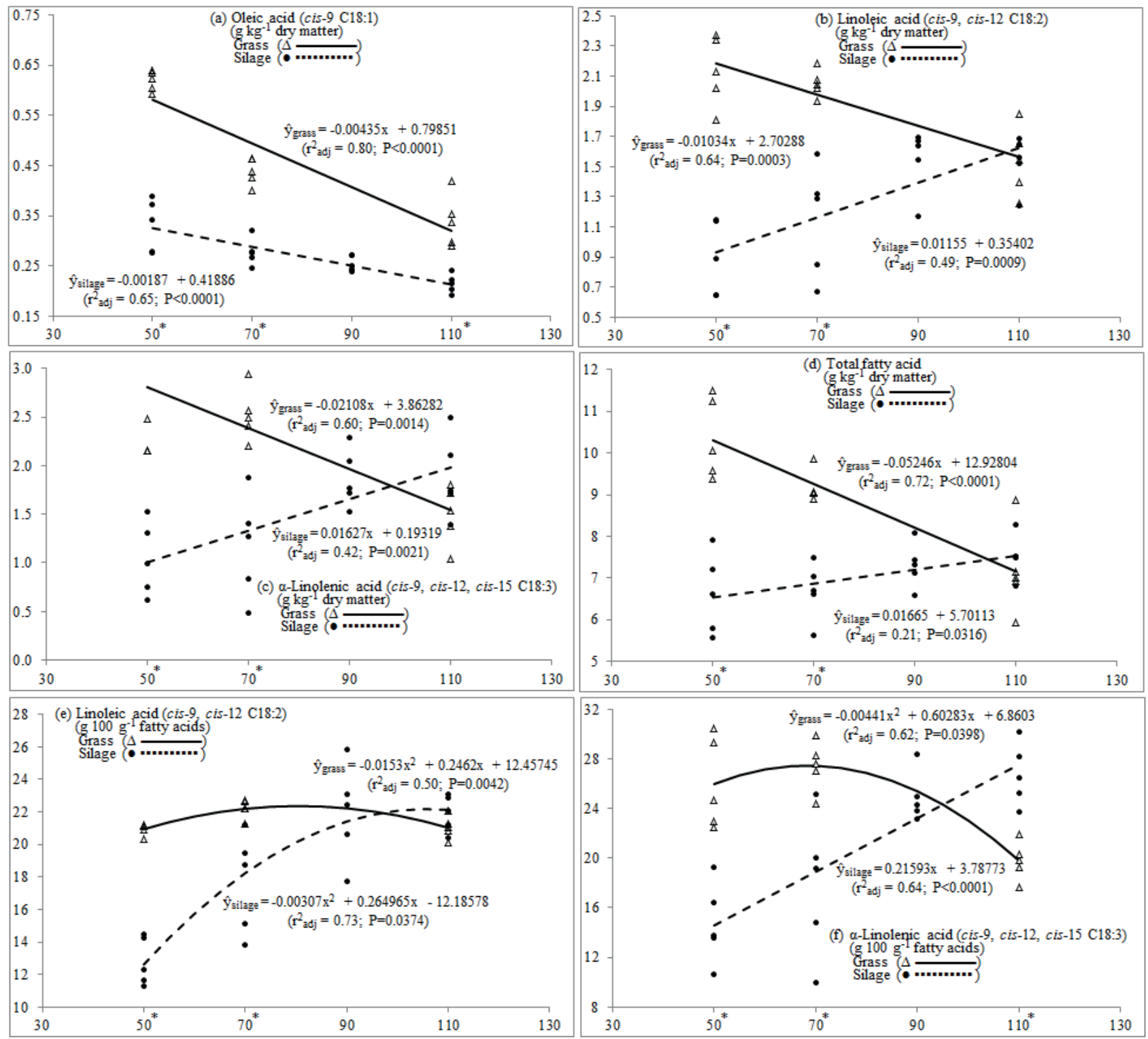

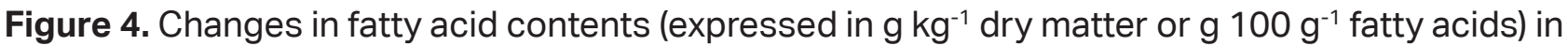
chopped grass and silage of BRS Capiaçu harvested at different regrowth ages (days). *Asterisks beside the regrowth age indicate a difference $(P<0.05)$ between chopped grass versus silage (paired t-test). 


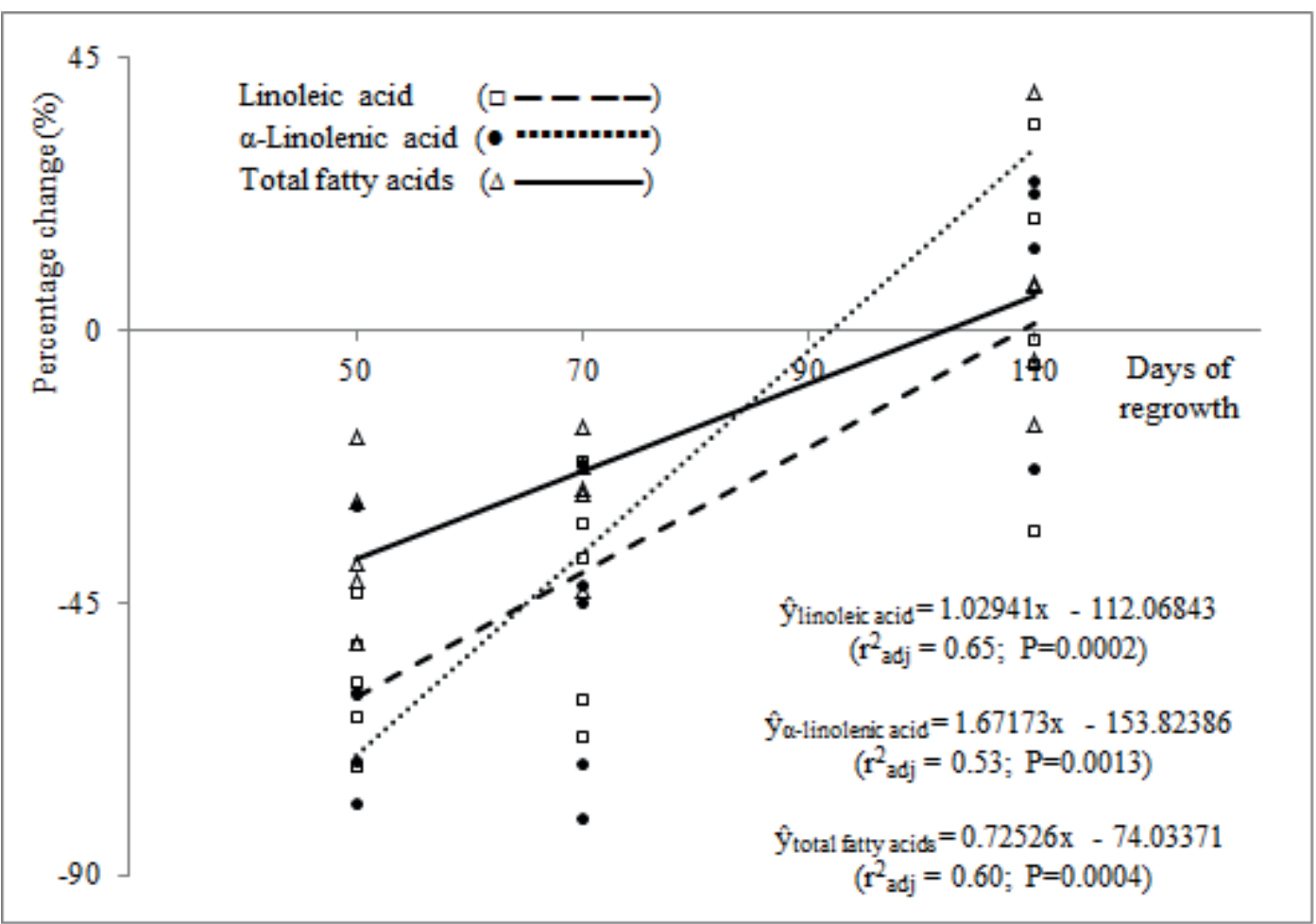

Figure 5. Percentage changes (\%) in the silage contents ( $\mathrm{g} \mathrm{kg}^{-1} \mathrm{dry}$ matter) of linoleic, $\alpha$-linolenic and total fatty acids in relation to those of chopped BRS Capiaçu elephant grass harvested at different regrowth ages.

There were linear $(P<0.0001)$ increases in the contents (g $100 \mathrm{~g}^{-1} \mathrm{FA}$ ) of lauric and myristic acids in the chopped grass, while quadratic effects $(P<0.05)$ were observed in the palmitic, stearic, oleic, linoleic and $\alpha$-linolenic acid contents as a function of regrowth age (Table 3; Figures 4e, 4f). The maximum

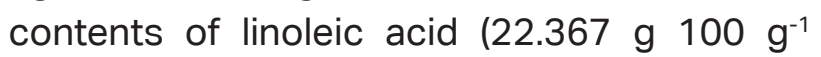

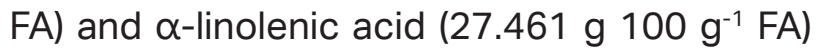
were estimated to occur at 80 and 68 days of regrowth, respectively. There were linear reductions $(P<0.01)$ in the silage lauric, palmitic, stearic and oleic acid contents (g $100 \mathrm{~g}^{-1} \mathrm{FA}$ ) as a function of regrowth age (Table 3 ). There was no linear or quadratic effect $(P>0.05)$ on the silage myristic acid content, while a quadratic effect $(P=0.0374)$ was observed on the silage linoleic acid content as a function of regrowth age (Table 3; Figure 4e); the maximum content

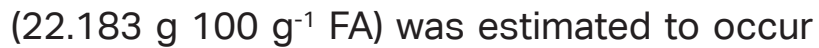
at 106 days of regrowth. The silage $\alpha$-linolenic acid content increased linearly $(P<0.0001)$ as a function of regrowth age (Table 3; Figure 4f). Compared to those of chopped grass, the silage lauric and palmitic acid contents (g 100 $\left.\mathrm{g}^{-1} \mathrm{FA}\right)$ were higher $(\mathrm{P}<0.05)$ at 50 and 70 days and lower $(P<0.05)$ at 110 days of regrowth (Table 3). For myristic acid (g $100 \mathrm{~g}^{-1} \mathrm{FA}$ ), the silage had a higher $(P=0.0046)$ content at 50 days, a lower content at 110 days $(P=0.0002)$ and a similar $(P>0.05)$ content to that of the chopped grass at 70 days (Table 3 ). Higher $(\mathrm{P}<0.05)$ stearic acid levels ( $100 \mathrm{~g}^{-1} \mathrm{FA}$ ) were observed in the silage at 50 and 70 days, which was similar $(P>0.05)$ to that of chopped grass at 110 days (Table 3 ). The contents of 
oleic acid ( $\left.100 \mathrm{~g}^{-1} \mathrm{FA}\right)$ were higher $(\mathrm{P}<0.05)$ in chopped grass at 50 and 110 days and similar $(P>0.05)$ to that of silage at 70 days of regrowth (Table 3). Higher $(P<0.05)$ linoleic acid contents (g $100 \mathrm{~g}^{-1} \mathrm{FA}$ ) were observed in chopped grass at 50 and 70 days, which was similar $(P>0.05)$ to that of the silage at 110 days of regrowth (Table 3; Figure 4e). For $\alpha$-linolenic acid (g 100 $\left.\mathrm{g}^{-1} \mathrm{FA}\right)$, the chopped grass showed higher $(P<0.01)$ levels at 50 and 70 days and a lower $(P<0.0001)$ content at 110 days of regrowth (Table 3; Figure 4f).

Table 3

Fatty acid (FA) composition (g $100 \mathrm{~g}^{-1} \mathrm{FA}$ ) of chopped forage and silage of BRS Capiaçu elephant grass harvested at different regrowth ages

\begin{tabular}{|c|c|c|c|c|c|c|c|}
\hline \multirow{2}{*}{ Fatty acid } & \multicolumn{4}{|c|}{ Regrowth ages (days) $^{a}$} & \multirow{2}{*}{ SEM } & \multicolumn{2}{|c|}{ P-value } \\
\hline & 50 & 70 & 90 & 110 & & Linear & Quadratic \\
\hline \multicolumn{8}{|c|}{ Chopped forage } \\
\hline C12:0 & $0.692 \mathrm{Bc}$ & $0.902 \mathrm{Bb}$ & * & $1.870 \mathrm{Aa}$ & 0.0587 & $<0.0001$ & 0.1498 \\
\hline C14:0 & $0.462 \mathrm{Bc}$ & $0.612 \mathrm{Ab}$ & * & $1.196 \mathrm{Aa}$ & 0.0490 & $<0.0001$ & 0.2946 \\
\hline C16:0 & 30.908 Bab & 29.307 Bb & * & $31.100 \mathrm{Aa}$ & 0.4973 & 0.4409 & 0.0278 \\
\hline C18:0 & $1.951 \mathrm{Bb}$ & $1.855 \mathrm{Bb}$ & * & $2.311 \mathrm{Aa}$ & 0.0567 & 0.0009 & 0.0156 \\
\hline cis-9 C18:1 & $6.021 \mathrm{Aa}$ & $4.745 \mathrm{Ab}$ & * & $4.724 \mathrm{Ab}$ & 0.2050 & 0.0044 & 0.0108 \\
\hline cis-9, cis-12 C18:2 & $20.954 \mathrm{Ab}$ & $22.215 \mathrm{Aa}$ & * & $21.073 \mathrm{Aa}$ & 0.2477 & 0.6894 & 0.0042 \\
\hline $\operatorname{LnA}^{b}$ & $25.973 \mathrm{Aa}$ & $27.442 \mathrm{Aa}$ & * & 19.792 Bb & 1.1541 & 0.0025 & 0.0398 \\
\hline \multicolumn{8}{|c|}{ Silage } \\
\hline C12:0 & $2.434 \mathrm{Aa}$ & $1.781 \mathrm{Aa}$ & $1.104 \mathrm{~b}$ & $1.055 \mathrm{Bb}$ & 0.2578 & 0.0006 & 0.3148 \\
\hline C14:0 & $0.826 \mathrm{Aa}$ & $0.718 \mathrm{Aa}$ & $0.685 a$ & $0.689 \mathrm{Ba}$ & 0.0638 & 0.1578 & 0.3989 \\
\hline C16:0 & $41.734 \mathrm{Aa}$ & $38.856 \mathrm{Aa}$ & $32.542 b$ & $29.498 \mathrm{Bb}$ & 1.8938 & 0.0003 & 0.9657 \\
\hline C18:0 & $2.943 \mathrm{Aa}$ & $2.628 \mathrm{Aab}$ & $2.234 \mathrm{~b}$ & $2.318 \mathrm{Ab}$ & 0.1541 & 0.0064 & 0.2187 \\
\hline cis-9 C18:1 & $4.818 \mathrm{Ba}$ & $4.457 \mathrm{Aa}$ & $3.423 b$ & $3.359 \mathrm{Bb}$ & 0.2226 & 0.0002 & 0.5183 \\
\hline cis-9, cis-12 C18:2 & $12.800 \mathrm{Bc}$ & $17.699 \mathrm{Bb}$ & $21.948 a$ & $21.934 \mathrm{Aa}$ & 1.0499 & $<0.0001$ & 0.0374 \\
\hline $\operatorname{Ln}^{b}$ & $14.719 \mathrm{Bb}$ & $17.846 \mathrm{Bb}$ & $24.929 a$ & $26.754 \mathrm{Aa}$ & 1.6393 & $<0.0001$ & 0.6981 \\
\hline
\end{tabular}

*Not analyzed; aFor each variable, means followed by the same letters, which are uppercase in the columns in the comparison between chopped forage versus silage in each regrowth age (paired t-test) and lowercase in the rows for comparison among days of regrowth, do not differ at $5 \%$ probability; ${ }^{b} \alpha$-Linolenic acid (cis-9, cis-12, cis-15 C18:3).

In the Mata Atlântica Biome of Brazil, depending on the form of use (chopped grass or silage), BRS Capiaçu is recommended for harvesting and supplying to dairy cattle at 50 to 110 days of regrowth (Pereira et al., 2016a). In response to the advance in the regrowth age, there are intense physiological, morphological and structural changes in the plant, which promotes inevitable losses in the nutritional quality of the forage and, consequently, in the silage. Decreases in the leaf/stem ratio, leaf maturation and senescence, cell wall thickening and lignification are among the main changes in the morphology and structure 
of elephant grass resulting from the increase in regrowth age (Ferreira, Abreu, Martinez, Braz, \& Ferreira, 2018; Maranhão et al., 2018). These aspects contribute to losses in the forage nutritional quality, which, in the present study, were mainly related to the decrease in the $\mathrm{CP}$ content, increases in the NDF, lignin and ADF levels and, consequently, reduction in IVDMD with the advance of regrowth age (Table 1; Figures 2a, 2b, 2e and 2f). For each increment of $1 \mathrm{~g} \mathrm{~kg}^{-1} \mathrm{DM}$ of CP, NDF, ADF and lignin, changes $(P<0.0001)$ of $+3.96,-1.57,-1.67$ and -3.74 in $\mathrm{g} \mathrm{kg}^{-1}$, respectively, were observed in chopped grass IVDMD, showing that CP and lignin were the factors most influential on IVDMD.

The main change in the chemical composition of the chopped grass occurred between the regrowth ages of 50 and 70 days, when reductions of $19 \%$ in CP content and $10 \%$ in IVDMD and increases of $9 \%, 10 \%$ and $54 \%$ in the contents of ADF, NDF and lignin, respectively, were observed $(P<0.05$; Table 1). However, there was an important increase $(P<0.05)$ of $48 \%$ in the DM content in the comparison between the forages harvested at 50 and 70 days of regrowth. In a study carried out with lactating cows fed chopped elephant grass-based diets, Soares et al. (2009) reported lower $(P<0.05)$ DM forage intake with 30 days of regrowth in relation to those cut at 45 and 60 days, which may be associated with its lower DM content. It should be noted that at 70 days of regrowth, the CP content is still above the minimum dietary content of 70 $\mathrm{g} \mathrm{kg}^{-1} \mathrm{DM}$ required to sustain microbial growth and support efficient fibrous carbohydrate digestion (Lazzarini et al., 2009). Considering all changes in the chemical composition, the forage obtained at 70 days still presented good nutritional value compared to that harvested at 50 days of regrowth. Between the regrowth ages of 70 and 90 days, the forage nutritional quality continued to fall, mainly due to the reduction of $20 \%$ in the CP content, which was below the recommended dietary minimum (Figure 2b), and the increase of $20 \%$ in the lignin content (Figure $2 f$ ), which was reflected in increases of $7 \%$ and $3 \%$ in the ADF and NDF levels (Figure 2e), respectively $(P<0.05 ;$ Table 1). Between the regrowth ages of 90 and 110 days, there was a decrease $(P<0.05)$ of $9 \%$ in the CP content and $10 \%$ in the IVDMD, and although the ADF and NDF levels stabilized $(P>0.05)$, there was also a $9 \%$ increase $(P<0.05)$ in lignin content (Table 1$)$.

Zailan, Yaakub and Jusoh (2018) studied the nutritive quality of fresh and ensiled elephant grass cultivars and concluded that the process of fermentation clearly decreased the nutritive value of the original forage. In the present study, this was also observed. Except for the EE content, which was always higher in the silages than in chopped grass regardless of the regrowth age, there were reductions of $12 \%$ to $16 \%$ in the IVDMD and increases of $6 \%$ to $11 \%$ in the NDF content of the silages produced at different ages of regrowth (Table 1). Except at 90 days, at the other regrowth ages, there were reductions of $9 \%$ to $26 \%$ in the silage CP contents compared to those of the chopped grass, and the CP contents in these silages were always below the minimum of $70 \mathrm{~g} \mathrm{~kg}^{-1} \mathrm{DM}$ recommended in the diet. The increase in the EE content in the silage compared to that of the original chopped grass corroborates the results of Arvidsson et al. (2009) and Bochicchio et al. (2015) and can be explained by the loss of watersoluble nutrients in the silo effluents or the fermentative products, thus concentrating the EE in the DM silage (Baumont, Arrigo, \& Niderkorn, 2011; Bochicchio et al., 2015). 
The effluent losses can reach $28.5 \%$ of the original wet mass of a chopped grass with 13\% DM ensiled manually in experimental silos made of PVC (Savoie, Amyot, \& Thériault, 2002). According to these authors, the average effluent chemical composition was 125, 290, 3.1 , and $126 \mathrm{~g} \mathrm{~kg}^{-1} \mathrm{DM}$ of MM, CP, ammonia $\mathrm{N}$, and soluble sugars, respectively. These results also partially explain the lower MM and CP contents in silages than in chopped grass (Table 1). The effluent DM losses and those due to fermentative activity (catabolization of nonlipid organic compounds, mostly watersoluble carbohydrates and proteins) could also contribute to NDF enrichment in silages (Alves et al., 2011; Liu et al., 2019). Indeed, regardless of the regrowth age, the silages had more NDF than chopped grass (Table 1).

There is a general perception that tropical grasses are difficult to ensile, partly because the maximum nutritional quality of their forage is reached when the DM content is still too low to allow desirable fermentation in the silo. Wilting the forage to 30\% DM prior to ensiling is a technique that can be used by small holders (Moran, 2005), but according to Daniel, Bernardes, Jobim, Schmidt and Nussio (2019), elephant grass is tall and has thick stems, which are difficult to wilt; moreover, wilting tropical grasses may increase field losses. In addition, wilting prior to ensiling reduces the total FA contents with significant losses in the contents of individual FAs, such as $\alpha$-linolenic and/or linoleic acids (Boufaïed et al., 2003; Dewhurst et al., 2006; Van Ranst, Fievez, De Riek, \& Van Bockstaele, 2009a). These losses are associated with the lipoxygenase system, a plant defense mechanism initiated in damaged tissues (Dewhurst et al., 2006). In the present study, wilting was not used to improve the fermentability of the ensiled forage mass. Thus, the best regrowth age for silage production is that in which there was a balance between the maximum nutritional quality of the forage to be ensiled and a DM content that allows rapid acidification of the silage and therefore efficient conservation of the ensiled forage. In the present study, for each increment of $1 \mathrm{~g} \mathrm{~kg}^{-1} \mathrm{DM}$ in the chopped grass, there was a reduction of 0.01 in the $\mathrm{pH}$ value of the silage $\left(P<0.0001 ; r^{2}=0.70 ;\right.$ Figure 3$)$. Tomich, Pereira, Gonçalves, Tomich and Borges (2003) proposed a system for the qualification of the silage fermentation process, associating the $\mathrm{pH}$ value with the silage DM content. In this respect, silages with DM contents less than $200 \mathrm{~g} \mathrm{~kg}^{-1}$, such as all those obtained in the present study (Table 1), should have $\mathrm{pH} \leq 4.0$ to achieve good fermentation quality, while those with $\mathrm{pH}>4.8$ would present low fermentation quality. Considering these criteria, only silages produced at the regrowth ages of 90 and 110 days would have good fermentation quality (Table 1) in addition to being equivalent in nutritional quality, since, except for the ADF content that was $4 \%$ higher $(P<0.05)$, the silage produced at 110 days of regrowth presented similar $(P>0.05) M M, E E, A D F$, lignin and $C P$ contents and IVDMD (Table 1). Using the linear equation, a silage $\mathrm{pH}$ of 4.0 was estimated to be obtained at 97 days of regrowth (Figure 3).

The increase in the silage DM content as a function of regrowth age reflects the increases in the chopped grass DM content. For each increment of $1 \mathrm{~g} \mathrm{~kg}^{-1}$ in chopped grass DM content, an increase of $0.95\left(\mathrm{P}<0.0001 ; \mathrm{r}^{2}\right.$ $=0.97$ ) was observed in the silage DM content. This increase was proportionally greater at the age of regrowth of 50 days $(+26 \%)$ than at 70,90 and 110 days $(+10 \%,+14 \%$ and $+6 \%$, respectively). This indicates, at least in part, that the effluent DM losses and/or 
those due to anaerobic fermentative activity were possibly greater at 50 days of regrowth, being gradually reduced as the DM content of the forage increased with the regrowth age. These supposed losses contributed to DM content enrichment of the silages, and since EE and NDF are less sensitive to anaerobic degradation in the silo (Alves et al., 2011), these nutrients were concentrated in the silage. For each increment of $1 \mathrm{~g} \mathrm{~kg}^{-1}$ in silage DM content, there were increases of $0.08 \mathrm{~g}$ $\mathrm{kg}^{-1} \mathrm{DM}\left(\mathrm{P}=0.0070 ; \mathrm{r}^{2}=0.44\right)$ and $0.70 \mathrm{~g} \mathrm{~kg}^{-1}$ DM $\left(P<0.0001 ; r^{2}=0.82\right)$, respectively, in the silage EE and NDF contents. On the other hand, as a function of the age of regrowth, it is expected that the nutrients most likely to leach, i.e., $\mathrm{MM}, \mathrm{CP}$, ammonia $\mathrm{N}$, and soluble sugars (Savoie et al., 2002) and most sensitive to anaerobic fermentative activity, e.g., watersoluble carbohydrates and proteins (Alves et al., 2011) had their levels reduced in the silages. Compared to the ensiled forages, the silage CP contents were reduced by $26 \%$, $17 \%, 14 \%$ and $9 \%$ at regrowth ages of 50 , 70, 90 and 110 days, respectively. For each increment of $1 \mathrm{~g} \mathrm{~kg}^{-1}$ in silage DM content, there were reductions $(P<0.001)$ of $0.20 \mathrm{~g} \mathrm{~kg}^{-1}$ $\mathrm{DM}\left(\mathrm{r}^{2}=0.70\right)$ and $0.51 \mathrm{~g} \mathrm{~kg}^{-1} \mathrm{DM}\left(\mathrm{r}^{2}=0.88\right)$ in silage CP and MM contents, respectively.

On average, the FAs showing higher concentrations in the chopped grass were palmitic, $\alpha$-linolenic and linoleic acids, accounting for approximately $76 \%$ of the total FAs. The average contents ( $100 \mathrm{~g}^{-1} \mathrm{FA}$ ) of the five major FAs (palmitic, $\alpha$-linolenic, linoleic, oleic, and stearic acids) were in the ranges compiled by Lopes et al. (2015) for chopped elephant grass. Linear reductions were observed in the chopped grass contents $\left(\mathrm{g} \mathrm{kg}^{-1}\right.$ DM) of all of these FAs as well as in the content of the total FAs as a function of regrowth age (Table 2; Figures $4 a$ to $4 d$ ). $\alpha$-Linolenic acid had the largest rate of decrease with maturity, corroborating the results of Khan et al. (2015), followed by palmitic acid and linoleic acid at $-0.021,-0.019$ and $-0.010 \mathrm{~g} \mathrm{~kg}^{-1} \mathrm{DM}$ day $^{-1}$, respectively. The daily reduction in the chopped grass total FA content was $-0.052 \mathrm{~g}$ $\mathrm{kg}^{-1} \mathrm{DM}$.

The chopped grass contents of oleic and linoleic acids ( $\mathrm{kg}^{-1} \mathrm{DM}$ ) were the most reduced, by approximately $45 \%$, in the comparison between the regrowth ages of 50 and 110 days. In this period, the reductions in the contents of the total FAs and linoleic and palmitic acids were $31 \%, 28 \%$ and $37 \%$, respectively. The magnitude of the individual FA reductions at each regrowth age in relation to reductions in the total FA contents was reflected in the results of chopped grass FA contents expressed in $\mathrm{g} 100 \mathrm{~g}^{-1} \mathrm{FA}$ (Table 3), where the maximum contents of linoleic acid

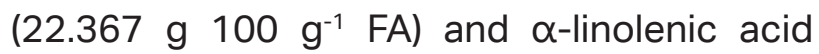
(27.461 g $100 \mathrm{~g}^{-1} \mathrm{FA}$ ) were estimated to occur at 80 and 68 days of regrowth, respectively. That is, at approximately 70 days of regrowth, the BRS Capiaçu forage showed high levels of the two main precursors for the formation of vaccenic acid in the rumen and, subsequently, for the synthesis of rumenic acid in the mammary gland.

Only in two previous studies were the elephant grass FA compositions presented as a function of plant maturity. Similar to the present study, Mojica-Rodríguez et al. (2017) also observed a reduction $(\mathrm{P}<0.05)$ in the elephant grass forage contents of stearic and $\alpha$-linolenic acids due to the increase in the regrowth age; the $\alpha$-linolenic acid levels at 21 , 42 and 63 days of regrowth were $0.46,0.35$ and $0.06 \mathrm{~g} \mathrm{~kg}^{-1} \mathrm{DM}$, respectively, showing much lower levels than those obtained in the present 
study. Additionally, corroborating the results of the present study, Khan et al. (2015) also observed reductions $(\mathrm{P}<0.05)$ in the contents of palmitic, linoleic, $\alpha$-linolenic and total FAs in elephant grass forage with advancing plant maturity. The linoleic, $\alpha$-linolenic and total FA contents of 2.36-2.90, 7.29-13.81, and 14.25$22.93 \mathrm{~g} \mathrm{~kg}^{-1} \mathrm{DM}$, respectively, were much higher than those obtained in the present study. The use of the elephant grass Mott cultivar, which has a high leaf:stem ratio, may be a possible explanation for this superiority, since according to Cabiddu et al. (2017) and Goossen, Kraft and Bosworth (2018), leaves have higher contents of total FAs than stems.

FAs in forage are present in membrane lipids, predominantly in thylakoid membranes of chloroplasts (Khan et al., 2015), and chloroplasts are the major site for de novo FA synthesis in the plant cell (Hölzl \& Dörmann, 2019). Leaves have chloroplasts in greater number and size than stems and other nonleaf organs (Li, Bai, Hu, Kuang, \& Lin, 2001), but during leaf senescence, there is a gradual reduction in the number of chloroplasts per mesophyll cell (Mae, Kai, Makino, \& Ohira, 1984; Ono, Hashimoto, \& Katoh, 1995). Chloroplast lipids are subject to constant turnover and are degraded during senescence (Hölzl \& Dörmann, 2019). In a study with the tropical grass Panicum virgatum (switch grass), Z. Yang and Ohlrogge (2009) demonstrated that at 60 days after sowing, the total FA content of the leaves began to drop, and at the late senescence stage of 121 days, the leaves had lost $80 \%$ of FAs. According to these authors, the daily average degradation rate of FAs was approximately $0.69 \mu \mathrm{g} \mathrm{mg}^{-1} \mathrm{DM}$. In elephant grass, advancement at the age of regrowth increases the proportion of stems and senescent leaves, reducing the leaf proportion in the plant and subsequently reducing the leaf/stem ratio (Ferreira et al, 2018; Maranhão et al., 2018). Therefore, corroborating Khan et al. (2015), it can be assumed that the decrease in leaf/stem ratio and leaf senescence with advancing maturity promoted a decline in chloroplast lipids, decreasing the forage FA content (Table 2).

Positive relationships $(P<0.01)$ were observed between chopped grass $\mathrm{CP}$ content (g kg-1 DM) and IVDMD ( $\mathrm{g} \mathrm{kg}^{-1}$ ) versus the contents of the total FAs and oleic, linoleic and $\alpha$-linolenic acids ( $\mathrm{g} \mathrm{kg}^{-1} \mathrm{DM}$ ). On the other hand, negative relationships $(P<0.05)$ were observed between the contents of the total FAs and oleic, linoleic and $\alpha$-linolenic acids (g kg-1 DM) versus the DM, NDF, ADF and lignin contents ( $\mathrm{g} \mathrm{kg}^{-1} \mathrm{DM}$ ) of chopped grass (data not shown). All of these responses are closely associated with the proportion and age of the leaves and stems of BRS Capiaçu. For each increment of $1 \mathrm{~g} \mathrm{~kg}^{-1} \mathrm{DM}$ of $\mathrm{CP}$, ADF and lignin in chopped grass, changes of $+0.077,-0.031$ and $-0.075 ;+0.014,-0.006$ and -0.013; and +0.029, -0.012 and -0.028 , respectively, in the total $F A$, linoleic acid and $\alpha$-linolenic acid contents ( $\left.\mathrm{g} \mathrm{kg}^{-1} \mathrm{DM}\right)$ were observed in chopped grass $(P<0.05)$. Stems have higher contents of NDF, ADF and lignin, while leaves are richer in $\mathrm{CP}$, total FAs, linoleic and $\alpha$-linolenic acids (Cabiddu et al., 2017). Therefore, the close relationship between CP and the total FA content can be explained, at least in part, by these nutrients being primarily located in the leaves (photosynthetic organs) rather than in stems (Glasser et al., 2013). As already discussed, the leaves have chloroplasts in greater number and size than the stems (Li et al., 2001), and chloroplasts are rich in proteins and lipids (Gedi et al., 2017). These latter authors showed that chloroplast- 
rich fractions extracted from green leaf tissues of the tropical grass Paspalum notatum presented 302 and $304 \mathrm{~g} \mathrm{~kg}^{-1}$ DM of protein and lipids. Therefore, in several studies, positive relationships between $\mathrm{CP}$ or $\mathrm{N}$ versus total FA contents were also observed (Boufaïed et al., 2003; Glasser et al., 2013; Cabiddu et al., 2017; Goossen et al., 2018).

Several studies have evaluated the effect of regrowth age on the forage FA profile, but few have studied this effect in silage. At first, it could be expected that the reduction in the forage FA levels due to the age of regrowth (as shown in the present study; Tables 2 and 3) will also occur in silage, since, according to Khan et al. (2015), most of the variation in FA content in grass silages was caused by differences in maturity at harvest. In fact, except for myristic acid, the silage contents of all other FAs were influenced by the age of regrowth (Tables 2 and 3). However, harvesting and ensiling agricultural practices and their influence on the biochemical changes related to the fermentation process in the silo can substantially alter the chemical composition of the forage that has been ensiled (Baumont et al., 2011) as well as its FA profile (Boufaïed et al., 2003; Van Ranst et al., 2009a; Glasser et al., 2013). Considering the dietary FAs that are precursors for beneficial FAs in products of ruminants, the linear increases in the silage linoleic and $\alpha$-linolenic acid contents, as well as in the total FAs, as a function of regrowth age, stand out (Table 2; Figures $4 b$ to $4 d$ ). Thus, while this effect of regrowth age is not clear, promoting an increase in the silage contents of these FAs, changes that occur inside the silo can help in understanding these results.

In the present study, the percentage changes in the total FA, linoleic acid and $\alpha$-linolenic acid contents ( $\mathrm{g} \mathrm{kg}^{-1} \mathrm{DM}$ ) of the silages compared to those of the chopped grass were $-58 \%,-62 \%$ and $-36 \%$ at 50 days; $-46 \%,-53 \%$ and $-27 \%$ at 70 days; $-13 \%,-5 \%$ and $-11 \%$ at 90 days (values for FA contents estimated by the linear equations); and $-0.6 \%$, $+26 \%$ and $+5 \%$ at 110 days of regrowth. At 50 and 70 days of regrowth, the total FA, linoleic acid and $\alpha$-linolenic acid contents $\left(\mathrm{g} \mathrm{kg}^{-1} \mathrm{DM}\right.$ and $\left.\mathrm{g} 100 \mathrm{~g}^{-1} \mathrm{FA}\right)$ were always higher $(\mathrm{P}<0.05)$ in chopped grass than in silage (Tables 2 and 3 ). However, at 110 days of regrowth, there was no difference $(P>0.05)$ in the contents $\left(\mathrm{g} \mathrm{kg}^{-1} \mathrm{DM}\right)$ of these FAs between chopped grass and silage (Table 2; Figures $4 \mathrm{~b}$ to $4 \mathrm{~d}$ ). The greatest losses in the total FA, linoleic acid and $\alpha$-linolenic acid contents of the silages compared to those of the chopped grass were observed at 50 and 70 days of regrowth (Table 2).

The main changes in the FA profile during ensiling are related to the action of plant lipases, which are activated after injury of forage tissue during harvesting operations, especially the leaves, which are less resistant than the stems because they are less lignified and therefore more sensitive to the action of tools (Baumont et al., 2011). Lipase and lipoxygenase activities are elevated soon after harvesting or in poorly preserved silages (Bueno, Lazzari, Jobim, \& Daniel, 2020), and the microbial lipases in silos do not contribute to a large extent to the lipolysis of forage membrane lipids (Ding et al., 2013; Gadeyne et al., 2016).

According to Tomich et al. (2003), silages with DM contents less than $200 \mathrm{~g} \mathrm{~kg}^{-1}$, such as all those obtained in the present study (Table 1), should have $\mathrm{pH} \leq 4.0$ to achieve good fermentation quality. This is related to the quality of fermentation in the silo. Plant lipases remain functional, and their activity is higher during the first two days of ensiling, declining 
with a reduction in silage $\mathrm{pH}$, and residual oxygen is consumed with the progress of ensiling (Han \& Zhou, 2013). Thus, considering that the rapid acidification of the silage might preclude FA cleavage (Bueno et al., 2020), the low DM contents of forages with 50 and 70 days of regrowth probably promoted a slow, prolonged and inefficient fermentation process in the silo (as indicated by the $\mathrm{pH}>5.0$; Table 1), leading to higher lipolysis in silage lipids (Van Ranst et al., 2009a), resulting in free FA accumulation in the silo (Van Ranst, Fievez, Vandewalle, De Riek, \& Van Bockstaele, 2009b). Considering that the most common substrates for plant lipoxygenases are $\alpha$-linolenic and linoleic acids, these FAs can be further oxidized by the actions of these enzymes to form hydroperoxides and are finally decomposed into aldehydes and ketones (Han \& Zhou, 2013) as well as be biohydrogenated into stearic acid by microbes in the silo (Liu et al., 2019).

According to Liu et al. (2019), lipase could also degrade lipids to release palmitic acid, which, because it is not oxidized by lipoxygenases, tends to increase in silage. Proportional increases $(P<0.05)$ in the contents (g $100 \mathrm{~g}^{-1} \mathrm{FA}$ ) of palmitic and stearic acids in the silages in relation to the chopped grass at the different regrowth ages were $+35 \%$ and $+51 \%$ at 50 days; $+33 \%$ and $+42 \%$ at 70 days; and $+11 \%$ and $+13 \%$ at 90 days (values for FA contents estimated by the quadratic equations). At 110 days of regrowth, the silage contents (g $100 \mathrm{~g}^{-1} \mathrm{FA}$ ) of palmitic acid were $5 \%$ lower $(P<0.05)$ than those of chopped grass, and there was no difference $(P>0.05)$ in the silage contents of stearic acid compared to that of chopped grass (Table 3). The greatest increases in the contents (g $100 \mathrm{~g}^{-1}$ FA) of palmitic and stearic acids in the silages in relation to those in chopped grass observed at 50 and 70 days of regrowth (Table 3 ) can be considered indicative that, at these regrowth ages, there was an intense activity of lipases, releasing palmitic, $\alpha$-linolenic and linoleic acids; the last two of these were further oxidized by lipoxygenases and biohydrogenated to stearic acid by microbes in the silo (Liu et al., 2019), as demonstrated by the significant reductions in their silage contents (Table 3). On the other hand, it is possible that the higher DM contents in forages with 90 and 110 days of regrowth promote a more rapid acidification of silage, precluding the oxidation of FAs (Bueno et al., 2020). This can be shown, at least in part, by the similar total FA, linoleic acid and $\alpha$-linolenic acid contents ( $\left.\mathrm{g} \mathrm{kg}^{-1} \mathrm{DM}\right)$ in the silages compared to the chopped grass at 110 days of regrowth (Table 2). The silage contents of the total FAs and linoleic and $\alpha$-linolenic acids showed correlations $(P<0.05)$ that were positive with the silage DM content $(r=0.52$ to $0.76)$ and negative with the silage $\mathrm{pH}(\mathrm{r}=-0.39$ to -0.61 ), which is indicative of the importance of these factors in the preservation of FAs in silages, primarily by a shorter fermentation and, therefore, fewer lipolysis, oxidation and biohydrogenation reactions, especially in linoleic and $\alpha$-linolenic acids.

At 110 days of regrowth, there was similarity $(P>0.05)$ inthetotalFA, linoleicacidand $\alpha$-linolenic acid contents ( $\left.\mathrm{g} \mathrm{kg}^{-1} \mathrm{DM}\right)$ in silages compared to those in chopped grass (Table 2). Considering the $\alpha$-linolenic acid content expressed in $\mathrm{g} 100 \mathrm{~g}^{-1} \mathrm{FA}$, there was even an increase $(P<0.05)$ in the contents in silage compared to those in chopped grass (Table 3 ). In studies in which there was maintenance or even an increase of the total FA and/or linoleic and $\alpha$-linolenic acid contents in the silages compared to chopped grass (Boufaïed et al., 
2003; Alves et al., 2011; Glasser et al., 2013; Bochicchio et al., 2015), the main explanation for this result is the degradation of silage DM during anaerobic fermentation (catabolization of nonlipid organic compounds, mostly watersoluble carbohydrates and proteins) and/or a loss of soluble components in silage effluent, which is rich in MM and CP (Savoie et al., 2002), with a resultant increase in the levels of the other components, such as EE, total FAs, linoleic and $\alpha$-linolenic acids (Boufaïed et al., 2003; Van Ranst et al., 2009b; Bochicchio et al., 2015). In fact, negative correlations $(P<0.05)$ were observed between the silage contents of $\mathrm{CP}$ and $\mathrm{MM}$ versus the silage contents of EE ( $r=-0.64$ and -0.54$)$, total FAs $(r=-0.46$ and -0.44), linoleic acid ( $r=-0.74$ and -0.66$)$ and $\alpha$-linolenic acid ( $r=-0.62$ and -0.58$)$.

\section{Conclusions}

BRS Capiaçu elephant grass must be harvested at up to 70 days of regrowth to obtain forage with good nutritional value and the highest levels of linoleic and $\alpha$-linolenic acids ( $\mathrm{g} \mathrm{kg}^{-1} \mathrm{DM}$ ).

To produce silages with adequate $\mathrm{pH}$ values and the highest levels of linoleic and $\alpha$-linolenic acids (g kg-1 DM), BRS Capiaçu must be harvested between 90 and 110 days of regrowth.

\section{Acknowledgments}

The authors gratefully acknowledge the Embrapa Dairy Cattle for financial support of this study and the technician Ernando Ferreira Motta who performed the analyses of fatty acid composition at the Laboratory of Chromatography of Embrapa Dairy Cattle.

\section{References}

Alves, S. P., Cabrita, A. R. J., Jerónimo, E., Bessa, R. J. B., \&. Fonseca, A. J. M. (2011). Effect of ensiling and silage additives on fatty acid composition of ryegrass and corn experimental silages. Journal of Animal Science, 89(8), 2537-2545. doi: 10.2527/ jas.2010-3128

Arvidsson, K., Gustavsson, A.-M., \& Martinsson, K. (2009). Effects of conservation method on fatty acid composition of silage. Animal Feed Science and Technology, 148(24), 241-252. doi: 10.1016/j.anifeedsci. 2008.04.003

Baumont, R., Arrigo, Y., \& Niderkorn, V. (2011). Transformation des plantes au cours de leur conservation et conséquences sur leur valeur pour les ruminants. Fourrages, 205, 35-46. Retrieved from https:// afpf-asso.fr/article/transformation-desplantes-au-cours-de-leur-conservationet-consequences-sur-leur-valeur-pourles-ruminants

Bochicchio, D., Comellini, M., Marchetto, G., Faeti, V., \& Della Casa, G. (2015). Modification of lipid fraction in ensiled high moisture corn. Italian Journal of Animal Science, 14(3), 466-470. doi: 10.4081/ijas. 2015.3899

Boufaïed, H., Chouinard, P. Y., Tremblay, G. F., Petit, H. V., Michaud, R., \& Bélanger, G. (2003). Fatty acids in forages. I. Factors affecting concentrations. Canadian Journal of Animal Science, 83(3), 501-511. doi: 10.4141/A02-098

Bueno, A. V. I., Lazzari, G., Jobim, C. C., \& Daniel, J. L. P. (2020). Ensiling total mixed ration for ruminants: a review. Agronomy, 10(6), 879. doi: 10.3390/agronomy 10060879 
Cabiddu, A., Wencelov, M., Bomboi, G., Decandia, M., Molle, G., \& Salis, L. (2017). Fatty acid profile in two berseem clover (Trifolium alexandrinum L.) cultivars: Preliminary study of the effect of part of plant and phenological stage. Grassland Science, 63(2), 101-110. doi: 10.1111/grs. 12159

Daniel, J. L. P., Bernardes, T. F., Jobim, C. C., Schmidt, P., \& Nussio, L. G. (2019). Production and utilization of silages in tropical areas with focus on Brazil. Grass and Forage Science, 74(2), 188-200. doi: $10.1111 / \mathrm{gfs} .12417$

Detmann, E., Valadares, S. C., F., Berchielli, T. T., Cabral, L. S., Ladeira, M. M., Souza, M. A.,... Azevedo, J. A. G. (2012). Métodos para análise de alimentos. Visconde do Rio Branco: SUPREMA.

Dewhurst, R. J., Shingfield, K. J., Lee, M. R. F., \& Scollan, N. D. (2006). Increasing the concentrations of beneficial polyunsaturated fatty acids in milk produced by dairy cows in high-forage systems. Animal Feed Science and Technology, 131(3-4), 168-206. doi: 10.10 16/j.anifeedsci.2006.04.016

Ding, W. R., Long, R. J., \& Guo, X. S. (2013). Effects of plant enzyme inactivation or sterilization on lipolysis and proteolysis in alfalfa silage. Journal of Dairy Science, 96(4), 2536-2543. doi: 10.3168/jds.20126438

Elgersma, A. (2015). Grazing increases the unsaturated fatty acid concentration of milk from grass-fed cows: a review of the contributing factors, challenges and future perspectives. European Journal of Lipid Science and Technology, 117(9), 1345-1369. doi: 10.1002/ejlt.201400469
Ferreira, E. A., Abreu, J. G., Martinez, J. C., Braz, T. G. S., \& Ferreira, D. P. (2018). Cutting ages of elephant grass for chopped hay production. Pesquisa Agropecuária Tropical, 48(3), 245-253. doi: 10.1590/1983-40632018v4851569

Gadeyne, F., De Ruyck, K., Van Ranst, G., De Neve, N., Vlaeminck, B., \& Fie, V. (2016). Effect of changes in lipid classes during wilting and ensiling of red clover using two silage additives on in vitro ruminal biohydrogenation. Journal of Agricultural Science, 154(3), 553-566. doi: 10.1017/ S0021859615001203

Gedi, M. A., Briars, R., Yuseli, F., Zainol, N., Darwish, R., Salter, A. M., \& Gray, D. A. (2017). Component analysis of nutritionally rich chloroplasts: recovery from conventional and unconventional green plant species. Journal of Food Science and Technology, 54(9), 2746-2757. doi: 10.1007/s13197017-2711-8

Glasser, F., Doreau, M., Maxin, G., \& Baumont, R. (2013). Fat and fatty acid content and composition of forages: a meta-analysis. Animal Feed Science and Technology, 185(1-2), 19-34. doi: 10.1016/j.anifeedsci. 2013.06.010

Goossen, C. P., Kraft, J., \& Bosworth, S. C. (2018). Fatty acids decrease in pearl millet forage from relative increases of pseudostem. Agricultural \& Environmental Letters, 3(1), 1-4. doi: 10.2134/ael2018.03.0016

Han, L., \& Zhou, H. (2013). Effects of ensiling processes and antioxidants on fatty acid concentrations and compositions in corn silages. Journal of Animal Science and Biotechnology, 4(48), 1-7. doi: 10.11 86/2049-1891-4-48 
Hölzl, G., \&Dörmann, P. (2019). Chloroplast lipids and their biosynthesis. Annual Review of Plant Biology, 70(1), 51-81. doi: 10.1146/ annurev-arplant-050718-100202

Instituto Nacional de Metereologia (2020). Estações e dados/dados metereológicos. Brasília, DF: INMET.

Khan, N. A., Cone. J. W., Fievez, V., \& Hendriks, W. H. (2012). Causes of variation in fatty acid content and composition in grass and maize silages. Animal Feed Science and Technology, 174(1-2), 36-45. doi: 10.1016/j.anifeedsci.2012.02.006

Khan, N. A., Farooq, M. W, Ali, M., Suleman, M., Ahmad, N., Sulaiman, S. M.,... Hendriks, W. H. (2015). Effect of species and harvest maturity on the fatty acids profile of tropical forages. The Journal of Animal \& Plant Sciences, 25(3), 739-746. Retrieved from http://www.thejaps.org.pk/ docs/v-25-03/19. pdf

Lazzarini, I., Detmann, E., Sampaio, C. B., Paulino, M. F., Valadares, S. C., Fo, Souza, M. A., \& Oliveira, F. A. (2009). Intake and digestibility in cattle fed low-quality tropical forage and supplemented with nitrogenous compounds. Revista Brasileira de Zootecnia, 38(10), 2021-2030. doi: 10. 1590/S1516-35982009001000024

Li, H., Bai, K., Hu, Y., Kuang, T., \& Lin, J. (2001). Differences between the number and structure of chloroplasts in leaves and in non-leaf organs of wheat. Belgian Journal of Botany, 134(2), 121-126. doi: 10.2307/ 20794486

Liu, Q. H., Dong, Z. H., \& Shao, T. (2018). Effect of additives on fatty acid profile of high moisture alfalfa silage during ensiling and after exposure to air. Animal Feed Science and Technology, 236, 29-38. doi: 10.1016/j.anifeedsci.2017.11.022

Liu, Q. H., Wu, J. X., \& Shao, T. (2019). Roles of microbes and lipolytic enzymes in changing the fatty acid profile, $\alpha$-tocopherol and $\beta$-carotene of wholecrop oat silages during ensiling and after exposure to air. Animal Feed Science and Technology, 253, 81-92. doi: 10.1016/j. anifeedsci.2019.04.004

Lopes, F. C. F., Silva, B. C. da M. e, Almeida, M. M. de, \& Gama, M. A. S. da. (2015). Lácteos naturalmente enriquecidos com ácidos graxos benéficos à saúde. In P. C. Martins, G. A. Piccinini, E. E. B. Krug, C. E. Martins \& F. C. F. Lopes (Eds.), Sustentabilidade ambiental, social e econômica da cadeia produtiva do leite: desafios e perspectivas (Chap. 13, pp. 237-309). Brasília: EMBRAPA. Retrieved from https:// ainfo.cnptia.embrapa.br/digital/bitstream/ item/128155/1/Cap-13-Lv-2015Sustentabilidade-Lacteos.pdf

Mae, T., Kai, N., Makino, A., \& Ohira, K. (1984). Relation between ribulose bisphosphate carboxylase content and chloroplast number in naturally senescing primary leaves of wheat. Plant \& Cell Physiology, 25(2), 333-336. doi: 10.1093/ oxfordjournals.pcp.a076718

Maranhão, T. D., Cândido, M. J. D., Lopes, M. N., Pompeu, R. C. F. F., Carneiro, M. S. S., Furtado, R. N.,... Alves, F. G. (2018). Biomass components of Pennisetum purpureum $\mathrm{cv}$. Roxo managed at different growth ages and seasons. Revista Brasileira de Saúde e Produção Animal, 19(1), 11-22. doi: 10. 1590/S1519-99402018000100002 
Mojica-Rodríguez, J. E., Castro-Rincón, E., Carulla-Fornaguera, J., \& LascanoAguilar, C. E. (2017). Efecto de la edad de rebrote sobre el perfil de ácidos grasos en gramíneas tropicales. Ciencia $y$ Tecnología Agropecuaria, 18(2), 217-232. doi: 10.21930/rcta.vol18_num2_art:623

Moran, J. (2005). Making quality silage. In J. Moran, Tropical dairy farming: feeding management for small holders in the humid tropics (Chap. 9, pp. 83-97). Devon: Landlinks Press.

Ono, K., Hashimoto, H., \& Katoh, S. (1995). Changes in the number and size of chloroplasts during senescence of primary leaves of wheat grown under different conditions. Plant \& Cell Physiology, 36(1), 9-17. doi: 10.1093/oxfordjournals.pcp.a07 8749

Palmquist,D.L,\&Jenkins, T.C.(2003).Challenges with fats and fatty acid methods. Journal of Animal Science, 81(12), 3250-3254. doi: $10.2527 / 2003.81123250 x$

Pereira, A. V., Lédo, F. J. S., \& Machado, J. C. (2017). BRS Kurumi and BRS Capiaçu New elephant grass cultivars for grazing and cut-and-carry system. Crop Breeding and Applied Biotechnology, 17(1), 59-62. doi: 10.1590/1984-70332017v17n1c9

Pereira, A. V., Ledo, F. J. S., Morenz, M. J. F., Bellini, J. L., Santos, A. M. B., Martins, C. E., \& Campolina, J. M. (2016a). BRS Capiaçu: cultivar de capim-elefante de alto rendimento para produção de silagem. (Comunicado Técnico, 79). Juiz de Fora: EMBRAPA Gado de Leite.

Pereira, A. V., Morenz, M. J. F., Ledo, F. J. S., \& Ferreira, R. P. (2016b). Capim elefante: versatilidades de usos na pecuária de leite.
In D. Vilela, R. P. Ferreira, E. N. Fernandes, \& F. V. Juntolli (Eds.), Pecuária de leite no Brasil: cenários e avanços tecnológicos (pp. 187-211). Brasília: EMBRAPA.

Savoie, P., Amyot, A., \& Thériault, R. (2002). Effect of moisture content, chopping, and processing on silage effluent. Transactions of the ASAE, 45(4), 907-914. doi: $10.13031 / 2013.9937$

Shingfield, K. J., Bernard, L., Leroux, C., \& Chilliard, Y. (2010). Role of trans fatty acids in the nutritional regulation of mammary lipogenesis in ruminants. Animal, 4(7), 1140-1166. doi: 10.1017/S17 51731110000510

Soares, J. P. G., Deresz, F., Salman, A. K. D., Aroeira, L. J. M., Oliveira, A. D., Verneque, R. S., \& Berchielli, T. T. (2009). Consumo de capim-elefante com diferentes idades fornecido para vacas leiteiras. Archivos de Zootecnia, 58(222), 298-300. doi: 10.4321/ S0004-05922009000200017

Sukhija, P. S., \& Palmquist, D. L. (1988). Rapid method for determination of total fatty acid content and composition of feedstuffs and feces. Journal of Agricultural and Food Chemistry, 36(6), 1202-1206. doi: 10.1021/jf00084a019

Tomich, T. R., Pereira, L. G. R., Gonçalves, L. C., Tomich, R. G. P., \& Borges, I. (2003). Características químicas para avaliação do processo fermentativo de silagens: uma proposta para qualificação da fermentação. (Documentos, 57). Corumbá: EMBRAPA Pantanal.

Van Ranst, G., Fievez, V., De Riek, J., \& Van Bockstaele, E. (2009a). Influence of ensiling forages at different dry matters and silage additives on lipid metabolism 
and fatty acid composition. Animal Feed Science and Technology, 150(1-2), 62-74. doi: 10.1016/j.anifeedsci.2008.08.004

Van Ranst, G., Fievez, V., Vandewalle, M., De Riek, J., \& Van Bockstaele, E. (2009b). Influence of herbage species, cultivar and cutting date on fatty acid composition of herbage and lipid metabolism during ensiling. Grass and Forage Science, 64(2), 196-207 doi: 10.1111/j.1365-2494.2009.00686.x

Yang, B., Chen, H., Stanton, C., Ross, R. P., Zhang, H., Chen, Y. Q., \& Chen, W. (2015). Review of the roles of conjugated linoleic acid in health and disease. Journal of Functional Foods, 15, 314-325. doi: 10.1016/j.jff.20 15.03.050
Yang, Z., \& Ohlrogge, J. B. (2009). Turnover of fatty acids during natural senescence of arabidopsis, Brachypodium, and switchgrass and in arabidopsis $\beta$-oxidation mutants. Plant Physiology, 150(4), 19811989. doi: 10.1104/pp.109.140491

Zailan, M. Z., Yaakub, H., \& Jusoh, S. (2018). Yield and nutritive quality of napier (Pennisetum purpureum) cultivars as fresh and ensiled fodder. The Journal of Animal \& Plant Sciences, 28(1), 63-72. Retrieved from http://www.thejaps.org.pk/ docs/v-28-01/09.pdf 